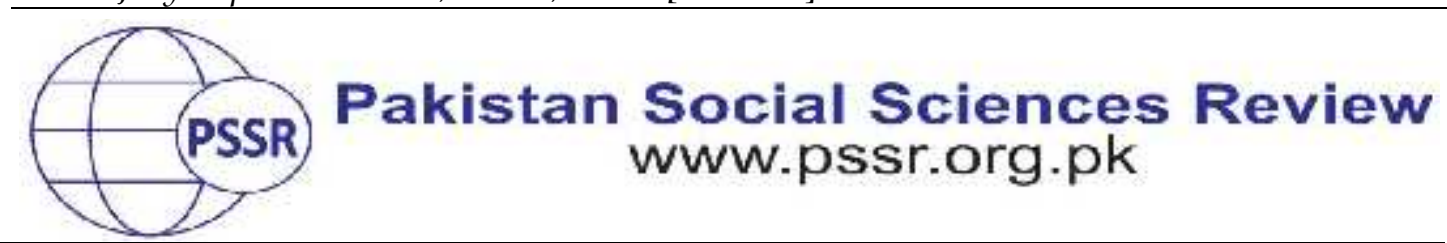

RESEARCH PAPER

\title{
Women Status and Politics of Welfare in Pakistan: A Theoretical Debate
}

Dr. Beenish Ijaz Butt

Assistant Professor, Department of Social Work, University of Sargodha, Punjab, Pakistan

\begin{tabular}{|c|c|}
\hline PAPI & \\
\hline $\begin{array}{l}\text { Rece } \\
\text { May } \\
\text { Acce } \\
\text { Augu } \\
\text { Onlir } \\
\text { Augu }\end{array}$ & $\begin{array}{l}\text { Defining women status in Pakistan } \\
\text { blend of culture, religion and state } \\
\text { Pakistani woman holds in the cou } \\
\text { the structure of cultural practices } \\
\text { state laws. Culturally, status of wo }\end{array}$ \\
\hline $\begin{array}{l}\text { Keywords: } \\
\text { Islamic } \\
\text { Jurisprudence, } \\
\text { Pakistan, } \\
\text { Politics of } \\
\text { Welfare, } \\
\text { State Laws, } \\
\text { Status, } \\
\text { Women }\end{array}$ & $\begin{array}{l}\text { of centuries old traditions of the Indian Subcontinent. Atter } \\
\text { spread of Islam, as a new religion was accepted by the masses } \\
\text { of sub-continent, but the traditional make up of those was the } \\
\text { fusion of Islamic and Indian culture. They adopted religion but } \\
\text { Islamic traditions were not exercised by the state under } \\
\text { Muslim rule. Women, in eyes of Islam, are not an inferior } \\
\text { creature; rather she is given certain rights while living in a } \\
\text { society which uplifts her status. But this is theoretical } \\
\text { explanation of the Islamic Social Welfare model for women as }\end{array}$ \\
\hline $\begin{array}{l}{ }^{*} \text { Corr } \\
\text { Auth }\end{array}$ & $\begin{array}{l}\text { countries around the globe and same is the case of Pakistan. } \\
\text { Pakistan after more than seven decades still has no selected } \\
\text { framework of ideology for women welfare. All the women } \\
\text { welfare and empowerment policies followed by national } \\
\text { constitution promulgated so far are a document only. Now } \\
\text { when the women violence issues in Pakistan are presented } \\
\text { through global media, it is related with the religion of the } \\
\text { country and pretending that it delegates women an inferior } \\
\text { status in society. But the reality is opposite to it as laws in } \\
\text { Pakistan are not in accordance with Islamic laws. Stratification } \\
\text { and discrimination lies in these state laws; hence are unable to } \\
\text { secure women's rights in Pakistan. Claiming of the } \\
\text { governments regarding women protection in the country is } \\
\text { just politics of welfare. }\end{array}$ \\
\hline
\end{tabular}

\section{Introduction}

Born and emerged as a state, Pakistan appeared on the world map on $14^{\text {th }}$ of August, situated in South Asia, possesses an area of 796,000 square kilometers, 
having borders with India, Iran, Afghanistan, China and Russia and is surrounded by Arabian Sea in the South (Government of Pakistan, 2020). Having a large provincial area and a capital territory, it possesses a population count of about 215.25million with an estimated annual growth rate of $1.8 \%$ (Government of Pakistan, 2021). According to UNDP report, earning of $63.3 \%$ population in Pakistan is calculated as less than US \$ 2 per day, $22.6 \%$ of population is living under US \$1 a day and the country is ranked 154th among 189 countries on UN's Human Development Index (HDI) 2020 rankings (United Nations, 2021).Still there is a lag between the 'haves' and the 'have not' in the country; undoubtedly there exists extreme poverty in the country. The situation is worst under the worldwide pandemic of COVID-19.Social protection by the state does not cover all the underprivileged segments of society but charity delivery (in the form of zakat, sadqat, fitranaetc) to the unprivileged ones is the tradition of the Muslim community. However, there are two parallel systems running in Pakistan at the same time i.e. formal system of charity delivery and informal system of charity delivery in Pakistan. Formal system is administered by the state machinery while informal charity delivery system is being carried out by the state citizens by themselves without the involvement of state at all. Having poor faith in state policies, informal charity delivery is popular in Pakistan and is the source of social safety nets of underprivileged ones.

\section{Women Status at a glance in Pakistan}

Women though constitute more than fifty person population of Pakistan, do not have equal opportunities and uplifted status as presented in the national and international statistics. Statistical data reveals that, gender inequality ratio is still high in Pakistan as compared to many other countries around the globe and is ranked as 154th among 189 countries of the world for the year 2019 (UINDP, 2020). Here, life expectancy for female is 68 years, under five mortality per 100,000 live births is 67.2(UNICEF, WHO, World Bank, UN DESA Population Division, 2020)maternal mortality ratio per 100,000 live births is 400 and inequality in education is recorded as 43.5 in 2019. Female and male labor force participation is calculated as 21.9 and 81.7 respectively (UNDP, 2020).

Within a family setup, a son is welcomed with joys and sweets in the society as compared to a daughter whose birth is considered as sorrow for the family showing her first status of an inferior being in the society. At the occasion of the birth of a male baby special ceremony are observed in all the provinces of the country (Butt \&Asad, 2016 a). This kind of gender inequality has been widely spread in the country and is deeply rooted in community. Girls' higher education is not a priority of the family rather their school dropout is common due to poverty (Shah, Haider\& Taj, 2019). Her role as a homemaker is heartedly accepted by all. When she has to economically run the family in case of a widow or divorced, feminization of poverty is the total result. Her health statistics are too poor encompassing the persistent social problems of girls' child marriages, premature child birth, domiciliary deliveries and high morbidity ratios. Under such patriarchal culture, family sets the 
normative values for all the genders in the society. Male head of the families, father, brother or husband have total decision making authority. Whereas the property rights are concerned, it is mostly transferred to the sons only (Butt \&Asad, 2016 b, Muzaffar, et. al. 2018). While Islam and the constitution of Pakistan delegates the inheritance rights left by parents and her husband. But family norms have no relevancy with the state laws and Islamic jurisprudence.

\section{Purpose, Method and Conceptual Framework}

The purpose of this article is to present a picture of women status in Pakistan since seven decades and the politics of welfare behind it through a theoretical debate. By using systematic literature review, this research will present new aspects and reflections about the said topic differentiating it from replica concepts about women status in Pakistan. The main limitation of this article is the available secondary literature (through library sources and open search engine) in Pakistan. By filling the existing literature gap, this systematic literature review will serve as an attempt to build a theoretical debate on actual status of women and the reality of forces which are responsible for shaping it.

Defining women status in Pakistan is not an easy task as it is a blend of culture, religion and state policies. Hence the actual status a woman possesses in Pakistan can be observed within the framework of cultural practices, applied Islamic laws and state laws. The explanation of these three aspects is presented in detail below.

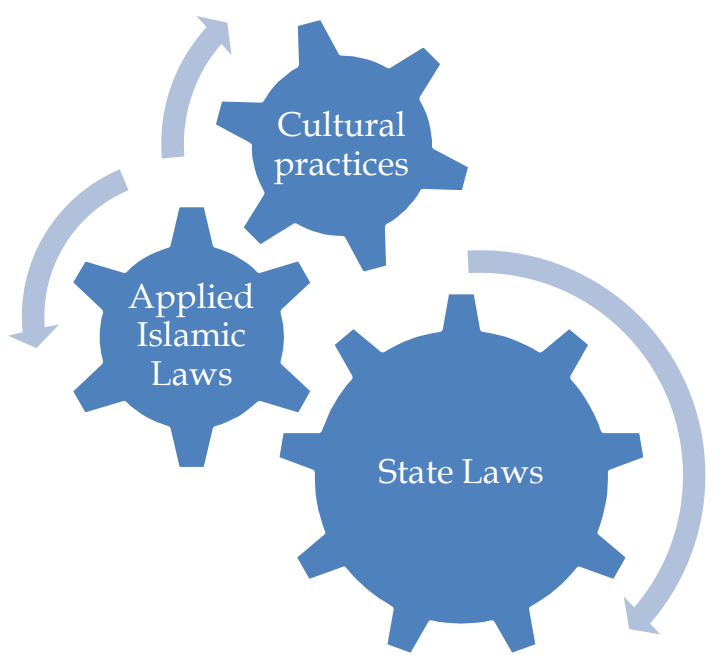

\section{Women across Pakistani Culture}

Taking start from the roots of the community, baby birth in Pakistan, whether in an urban or rural area, is accompanied by the question of baby's sex determination. No matter what is the place of child delivery, at home or in hospital, the person or nurse coming from the labor room is asked about the sex of a child; a 
son or daughter. Even the tip given to the nurse or unskilled attendants depends upon the sex determination of a child. For a baby boy she is given heavy tip, while for a baby girl she is given nothing sometimes. This moment is the start of social stratification which a women faces throughout her life in the country. Role and status description may be different in a society, but assigning lower status to women on the sex determination is discrimination. On constitutional pages men and women are equal but on actual grounds they are not. Societies have multi-cultural groups which do not possess equal status and equal power. On factual grounds, power of a an individual or group is reliant on the class in which they are born; women by virtue of their sex identification are born into a lower group and class in comparison with men in their societies. Since centuries, women are observed at an inferior status surrounded by male domination, inequalities in health and education, lack of legal safety and economically poor around the globe. In most of the third world countries of the world patriarchy is the most prominent feature of the society. This phenomenon is found at a highest degree in South East Asia, North Africa and Middle East.

Experts are of the view that women who live in a circle of patriarch cannot break it rather compelled to move around it and find no other way. The patriarchy is a historic creation that took over 2500 years to develop and male dominance is historic which is based on "biologically determined situation" and turned into "culturally created and enforced structure" over time (Sultana, 2012). Further explanation of women's lower status in the country can be linked with the colonialism in Asia. As colonies, the cheap labor was fruitful for the Britain and they did not share the profit with the natives which directly influenced the indigenous culture and resulted in lower women status. Consequently, efforts to influence the gender equality are often resisted with the charge of Western cultural imperialism.

In contrast, it is claimed that Pakistan is an Islamic state since 74 years but actual cultural practices give a lower status to the women in the country. Islam delegates immense importance to women as mother, wife or sister.

\section{Women Status under Islamic Jurisprudence}

Status of women in Islamic counties is questionable in the non-Islamic states. They perceive Muslim women as submissive, illiterate and availing no rights. Some accept it as true when actual status of women is observed in their communities. But debates of western writers become conflicting when women status is under reading as per the Islamic jurisprudence. Islamic jurisprudence describes the health, education, nuptial, dower and economic rights of women; no matter they belong to any caste color, creed or country.

As it is said in Holy Quran, 
And among His signs is this, that He created for you mates from among yourselves that you might live in tranquility with them and He put love and mercy between your (hearts); Verily in that are signs for those who reflect (Al-Quran, 30:21).

The Holy Prophet Mohammad (PBUH) explained the rights of men and women in his last sermon saying that,

The best of you is he who is best to his family, and I am the best among you to my family (Tirmidhi, 245:3057).

Marriage is a sacred announced contract between a Muslim man and a woman in their society. Even women used to live as slaves in Arab before the announcement of Islam. But Islam has given her marital rights in the society at that time when there was widespread ignorance among the masses. SalahuddinYousaf while ccommenting on verse 4:24 explains as, there are four essentials of Nikkah in Islam as i) consent from both sides. ii) To pay the dower. iii) The purpose of Nikkah is marital ties not only lust fulfillment. iv) Presence of witnesses.

Under first essential of Nikkah i.e. consent for Nikkah, it is forbidden to marry her forcefully under Islamic law. SalahudinYousaf, writing the tafseer (commentary) of the above verse writes that, before the advent of Islam, women were violated as after her husband's death, her family members used to inherit her like the property of her husband. They used to marry her forcefully with themselves or with their brothers or nephews. Even step son used to marry his step mother after his father's death or she was never married anywhere. Islam has forbidden all these kind of violence. Once a virgin girl came to the Holy Prophet (PBUH) and stated that her father had married her against her will, so the Prophet (PBUH) allowed her to exercise her choice (Sunan Abu-Dawud, 11: 2091). So in the light of above discussion, Islam guarantees the right to a woman that she cannot be forcefully married to any person and her consent must be asked for Nikkah.

The second essential part of Nikkah is Dower (Mehr), which is defined as a sum of money, or other property movable or immovable, payable by a man to a woman on or after her marriage with him, as a consideration for agreeing to marry him on compulsory basis whether it is Mehr-e Moajjal (prompt dower) or Mehr-e Mowajjal (deferred dower). In the ignorant eras, women had no nuptial advantages. On the other side Islam gave women their economic nuptial rights in the form of dower. It is a compulsion to pay the dower to the wife by the husband and it is her incontrovertible right.

Unlike other religions, which do not permit divorce even under any extreme condition, divorce (though disliked by Allah Almighty) is allowed under certain conditions under Islamic law. Both husband and wife are instructed to pursue all possible remedies if their marriage is in danger. Divorce is allowed only when there is no other way out left. In a nutshell, Islam allows divorce, yet it also discourages it by different means. Islam does recognize the right of divorce for both partners to end their nuptial relationship. Holy Quran has given a proper way of divorce in Sura 
Talaq and even there are still some rights which are given to women through the divine orders as

But if ye decide to take one wife in place of another, even if ye had given the latter a whole treasure for dower, take not the least bit of it back: Would ye take it by slander and a manifest wrong (Al-Quran, 4:20).

Also

It is not lawful for you (Men) to take back any of your gifts except when both parties fear that they would be unable to keep the limits ordained by Allah. There is no blame on either of them if she give something for her freedom. These are the limits ordained by Allah so do not transgress the (Al-Quran, 2:229).

Syed Abul-Ala Modoodi (1996) has explained this verse as, dower, clothes, jewelry etc, which a husband has given to his wife; he has no right to take anything back. Moreover it is against the moral values of Islam to take back one's gift which he has given to anyone. He says that this act resembles a dog who intake his vomit according to a Hadith. But especially it is very shameful for a husband that he keeps everything in his custody which he has given to his wife, at the time of divorce. So it is not allowed under Islamic law that after divorce, husband can snatch anything from her, rather it is ordered to give her with good gestures.

Education has been greatly emphasized in the light of Islam. Though statistics show high female illiteracy rate among Muslim countries and it is assumed that women are kept uneducated there but the roots of such customs are not found in Islamic Shriah (law). I will simply quote the first revelation of Quran which states,

Read! In the name of your Lord Who has created (all that exists). He has created man from a clot (a piece of thick coagulated blood). Read! And your Lord is the Most Generous. Who has taught (the writing) by the pen. He has taught man that which he knew not (Al-Quran, 96:1-5).

These first verses of the Holy Quran to be revealed to the Holy Prophet shows the importance of education. The first word of the verse is Iqra, means 'read' in Arabic language and it implies the concepts of learning, exploring, and seeking knowledge. These verses clearly depicts that Allah firstly talked the Holy Prophet Muhammad (PBUH) on the topic of education which shows the importance of education in Islam. Further, there is no separate order all the sexes; i.e. men, women or transgenders, rather the whole humanity is addressed to get education. Seeking knowledge is important for all the Muslims in the society, both men and women have to fulfill their duties and responsibilities. So women formal or informal education is not prohibited in Islam, it's just due to cultural impacts in different societies that women are kept illiterate. But the practice of such rules is not seen in Islamic countries. Even religious leaders never promote female education in these countries. As a result women have a very poor literacy rate in Islamic countries. 
Islamic jurisprudence does not provide poor economic status to women rather delegates her right to keep and inherit property. Islam has given rights and opportunities in economic fields both for men and women. Women economic status in Islamic law can be discussed in two aspects:

i) Women independent earning

ii) Her inheritance rights

On the first hand, a woman can have an economic independent position under the Islamic law. Quran guarantees women the right to earn and to maintain their property. She can earn through her job or business. In the pre-Islamic Arab, and Prophet Mohammad (PBUH) used to take the goods for business which belonged to Hazrat Khadeeja (R.A). Further Arabs used to send their children with maids in a healthy environment for the better nourishment as Prophet Mohammad (PBUH) was sent with Sadia Haleema for which she was paid by his family. These two women in the Prophets life were income generators in the society. After the revelation of Islam, the same practices were continued at that time without any limitations.

Inheritance is another aspect of a woman's life which is acknowledged by the Islamic law. She has full right to have, to sell or lease any of her assets in the society. She is eligible for her inheritance, no matter married or unmarried. Islam explains the division of one's property as clearly described in Sura Al-Baqra and Sura AlNisa in the Holy Quran. According to the prescribed division of property in Holy Quran, it is divided between the descendants without any discrimination. As Quran explains,

"Allah commands you as regards your children's (inheritance): to the male, a portion equal to that of two females; if (there are) only daughters, two or more, their share is twothirds of the inheritance; if only one, her share is a half. For parents, a sixth share of inheritance to each if the deceased left children; if no children, and the parents are the (only) heirs, the mother has a third,; if the deceased left brothers (or sisters), the mother has a sixth. (The distribution in all cases is) after the payment of legacies he may have bequeathed or debts. You know not which of them, whether your parents or your children, are nearest to you in benefit; (these fixed shares) are ordained by Allah. And Allah is ever All-Knower, Allwise (Al-Quran, 4:11).

Many non-Muslims argue that daughters of Muslims are given half the share in the inheritance as compared to their brothers. They consider it a sign of gender inequality among Muslims but it is not true. A careful reading of this verse shows that the Quran has taken care to give women a share in property of the deceased not only as a daughter but also as a mother. Similarly they also inherit as a wife according to the Quran(Al-Nisa 4:7). All her share as inheritance is like a gift for her and she has a right to spend it by her choice as it is also clearly mentioned in the Islamic jurisprudence that she has no economic responsibility. In the pre-Islamic period there was no regular law in this respect. Sometimes they inherited property, sometimes they did not. 
But all explained above seems a theoretical explanation of the Islamic Social Welfare model for Women as it is hard to find in the policies of the Islamic countries around the globe. Women, in eyes of Islam, are not an inferior creature. Rather she is given certain rights while living in a society which uplifts her status. There are certain natural biological and psychological differences between the both sexes. Basing on their differences men are said as "maintainers" in Holy Quran, and they are given economic responsibility of their wives and families. On the other hand, women are on the receiving hands. It is the duty of their fathers and husbands to fulfill their all kind of economic, education and health responsibilities according to his affordability. In addition to this, she is given dower as her own gift and her due property share. So one can say that women are given respectable status under Islamic law. She is allowed to earn if necessary but not compulsory, only she has keep the limits of chastity according to the law. Such limits of chastity are ordained for all the sexes under Islamic jurisprudence.

The focus of Islamic approach is not only focused on community rules but also individual rights, and women of all caste, color creeds are given education, health and property rights in a dignified manner. The fact behind women poor status in Muslim states is rooted in the fact that Islamic laws are not promulgated by the governments of these states.

\section{Women Status under State Laws}

History reveals that Pakistan appeared on the world map in order to enable Muslims to have a peaceful separate country where they will not face discrimination on the basis of religion or culture. But there is still an identity crisis that whether Pakistan can be labeled as an Islamic State or a Muslim Majority State. The tension between these two concepts has made women's status a question in the society during the last 74 years. The journey of women status is accompanied by a different story in every decade of Pakistan's history and preoccupied by the colonial rule.

Like other pre-colonial independent states, Pakistan inherited Britain law promulgated during colonial period. But 1947 did not only divide the land for the two states but the other elements also. The British strengthened their own power and that of the elite enhancing and promoting the subordination of women in the subcontinent (Mumtaz and Shaheed, 1987). But here there was a clear difference between the Hindu women's sufferings and Muslim Women's sufferings. Hindu women have to face the customary crimes of Satti and Devadasi. Under Satti custom, Hindu society used to burn a young alive widow with the funeral of her husband. Another custom under which Hindu women were made Devdadasis is defined as The devadasi practice is one in which low-caste girls, as young as five or six, are "married" to a Hindu Goddess and sexually exploited by temple patrons and higher caste individuals by Indian historian (Shingal, 2015). He documented it as "Temple Prostitution in India". The said practice of devadasis began to diminish under Muslim and British rule. Lee (2011) argues that successful invasion of North India by the Islamic rulers destroyed many Hindu temples in the region resulting in the shelter less devadasis 
and they were compelled to dance at wedding feasts as society did not absorbed them in its social structure. It brought a situation which made it difficult to make dancing and prostitution inseparable in India at that time until British rule outlawed the devadasi practice in 1924 and banned prostitution in the entire country. At legal platform, the laws dealing with these social problems among Hindu families was forcefully promulgated by the state but this law has nothing to do with the status of the Muslim women in the society.

Under the newly enforced legal system, religious and customary laws were replaced by new British laws governing the theft and adultery, land, evidence, and property transference. On the other hand, British law, in fact deprived Muslim women to inherit property. The adoption of Hindu customary law (which deprives Hindu women to administer property on behalf of their minor sons), deprived Muslim women as Islamic law was opposite to it. It resulted in protest and the Muslim Personal Law, 1937 was enacted to secure Muslim women rights. With this confused status of women they left subcontinent in 1947 (Mumtaz and Shaheed, 1987).

A widespread abduction, assassinations and suicides of women at the time of migration of 1947 between India and Pakistan welcomed women at the doorstep of newly born state. There was no talk of women rights in the country on legal grounds in the first decade after its creation except the activities of APWA (All Pakistan Women Association) which was not a solution to uplift women lower status sin the society. The journey of women status under state laws started in 1960s under Ayub Khan's progressive policies to modernize Pakistan in promoting economic and social development. One of such progressive steps was the promulgation of Muslim Family Law Ordinance (MFLO) in 1961 providing women rights in marriage, divorce, inheritance, and custody of minor children. But other side of the coin reveals that concubine practice is a common across the cultures and Indian subcontinent was not an exception. As an open fact they were refused to social or economic security in the society. This grave issue was raised by a non-governmental organization working for women welfare resulting in promulgating MFLO, 1961 which could not prove to be effective for women in Pakistan. The said law was greatly disapproved by the religious groups (Butt, Abbas and Ashiq, 2020).

But the sun rise 1970s and 1980s in Pakistan brought a modified legal status for Pakistani women but it could not be proved beneficial for women status. Under constitution of 1973, state started taking welfare measures in the country but the hang ship of the prime minister by military regime of the country sent the constitution on the background and late 1970s brought Hudood Ordinance with the slogan of "Islamization of Laws" in the country. In contrast to the title, the said law did not differentiate rape and adultery in an Islamic state (Qureshi, 1997). Hence, when talking about women's sexuality in an Asian patriarchal society without authentic testimony, it destroyed her whole social life and also the other women of her family and it happened in 1980s in Pakistan. In cases of pregnancy, Hudood Ordinance charged women under fornication because the law did not draw a clear line between rape and fornication. Further it did not accept a woman's testimony in 
case of rape. Even the legal experts of Pakistan and the Shriat Court were silent about the abolishment of the law. Though Muslims have clear interpretations of the said issue and crime in Quran but it could not be observed under the banner of "Islamization of laws". Policies under Islamization were distinct and control over women became the key marker of the state's adherence to religious norms (Khan, 2019). To the women rights groups of the country, the said law was promulgated by the General's own will.

The decade from 1989 to 1999 witnessed the highly marked political instability in Pakistan when the two leading political parties were busy in power snatching after the plane crash of Zia in 1988. Women uplifted status was not a priority of these two successive governments. This political atmosphere ended in martial law again in the history of Pakistan. After the 9/11 incident, Pakistan has to reassess its place in the globe. In order to improve Pakistan's position in the international community, women rights card was played to improve women's legal status in Pakistan with "Women Protection Slogan". Under this liberal environment, the newly signed CEDAW was resulted in passing the National Policy for Development and Empowerment of Women (NPDEW) and mirrored in the national legislation. Starting from the reshaping of Hudood Ordinance (regarding rape and fornication) to the banning of forced marriages, domestic violence, harassment at workplace, Vitriol age, child marriages. Domestic friction was obvious and came from the Islamic political party by claiming the changes being made are anti-Islamic. The $18^{\text {th }}$ amendment provincial autonomy in the country also brought laws pertaining to women laws. But the state of women protection is still at an alarming situation with the rise in rape cases and brutal assassinations of women in the country.

Now when the women violence issues in Pakistan are presented through global media, it is related with the religion of the country pretending that it delegates women an inferior status in society. But the reality is opposite to it as laws in Pakistan are not in accordance with Islamic laws. Stratification and discrimination lies in these state laws; hence are unable to secure women's rights in Pakistan

\section{Women Status and Politics of Welfare}

In the western world, Muslims are spectated as poor, illiterate, socially disorganized, fundamentalist and corrupt at different level; which is not entirely untrue. The plight of citizens living under underprivileged circumstances presents its proof. Keeping the citizens poor, bonded in the name of religion, common rapes and murders without justice does not fall under Islamic jurisprudence rather it is against Islamic teachings. The fact is that Islamic states are misnomers of Islam. As at official level it is claimed that state religion of Pakistan is Islam but on actual grounds it is a state where Muslims are in majority. Muslim population of Pakistan whether migrated or native of this geographical area, hoped to live in a society where there will be justice, peace and equality of opportunities. But the politics of conspiracies for own gain has become the political culture in Pakistan. Massive 
corruption, extended embezzlement, persistent heavy debts, sending national wealth in off shore accounts is a common practice of elites which could never be punished by the state. All the state institutions are self-defeating; promoting culture of corruption. Ironically constitutional institutions like Council of Islamic Ideology (CII) was constituted to guide the laws repugnant to Islam but it proved a dummy structure that had no influence at all. The rulers of Pakistan are irreligious their sole religion is politics while the ruled are still in the dreams of the past glories of Islam but do not possess power among international community.

Status of women across cultural frame is a product of centuries old traditions of the Indian Subcontinent. Pakistan possesses the geographical area which was a part of the Indian sub-continent. In pre-Islamic rule of India, Hinduism was the religion of Indians, Sanskrit was the prevailing language, region was divided into small empires having civil wars, social stratification was a common feature and women were ranked as" Devadasis" since $6^{\text {th }}$ century who used to dedicate their whole lives to the Lords of the temples where had to dance as a ritual of the temples, by sacrificing their whole nuptial, family and social life (Mondal, 2017). The overall status of women in Hindu society was accepted as submissive to the family, illiterate, married at early age and widows were treated brutally under Satti and devadasi custom.

Here Islam as a religion was introduced and continued to spread as a result of trade between the Arab Muslims and Indians. History of such trade is even historically documented in pre-Islamic Arabia. Along with the trade, historic Arab conquest of Sindh took place under the famous Muslim commander, Muhammad bin Qasim in 711followed by unsuccessful invasions of Makran (Baluchistan) between 664 to 670 . Muslim rule in subcontinent India continued from invasions of Mehmood Ghazni, defeat of Prithvi Raj Chohan by Mehmood Ghauri in 1192, establishment of Delhi sultanate till the Mughal dynasty from 1530 to 1712. Muslim rule started a new socio-cultural, religious and political atmosphere in the region. Islam as a religion was accepted by many Hindus of the India, now they were Muslims but the traditional make up of those was the fusion of Islamic and Indian culture. They adopted religion but Islamic traditions were not exercised by the state under Muslim rule. Social stratification was still a feature of the Indian society. Prevalence of Purdah (seclusion) among Muslims women restricted them to home based religious knowledge, they used to acquire if there was a religious literate woman at home or in neighbors otherwise Muslim women could not read Quran. Girls' child marriages were common as before. Muslim rule did not provided safety nets to widow, orphans or destitute at state level. Women were deprived of woman's right to family property. Under British rule there was no difference in Muslim and Hindu women status as both were illiterate and had no choice of getting education, married at early age and had no social security by the state. The laws promulgated by British government did not elevate women status in the society. The concluding point is that the Hindu rule, Muslim rule and British rule did not provided prowomen policies. It was not the priority of all the mentioned rules and promulgated women laws were just the byproduct of the protests of women at different times. 
With all these realities, women started their status journey in Pakistan. Pakistan after more than seven decades still has no selected framework of ideology for women welfare. All the women welfare and empowerment policies followed by national constitution promulgated so far are a document only.

Discussing women status within the framework of ideologies of welfare, there are different models across the globe. In the Asian countries like Pakistan, there is a typical distinction of the left wing and the right wing. Groups talking about religious ideology are labeled as the followers of the right wing philosophy in Asian countries which is not right. Religion as ideology of welfare is different than the right and left wing as Baldock, (2011) has explained different models of welfare ideology and explains the right, the middle, the left, new social movements (feminism, anti-racism and environmentalism) and religion. Here family structures are following the value system which matches with the right wing philosophy. State under its constitution though claims that state laws will be in accordance with the Islamic laws but is unable to fulfill this promise. Domestic violence laws in the second decade of the present century are totally rejected by the right wing philosophy and are labeled as inclusion of left wing philosophy. New social movements are not in vogue in Asian countries and uttering the terms like feminism in Pakistan is labeled as the rebels. There is no defined ideology according to which government in Pakistan has provided welfare in order to improve women status in the country. Government in different decades has failed to develop a nexus between the different ideologies and hence women status is still poor as she is easily violated even brutally murdered in the country. As a developmental welfare state, Pakistan falls in the category of an emerging rights-based developmental welfare state (Kohler, 2014) and health, education and social protection rights of citizens are based on country's constitution. Still here is confusion for the citizens; as constitution delegates all the Islamic rights to the citizens but conservative wing has quoted 'Islamization' title over their ideologies and when they present a social policy, it results in an amalgamation of the policies which are not Islamic at all. If hypothesized, there is a conglomeration welfare ideology of women welfare in Pakistan. Different governments has adopted different ideologies for the welfare provision to the women to fulfill their own political motives and uplifted women status has never been their priority since seven decades. Thus state laws, culture and religion has been indissolubly entangled in Pakistan to keep the citizens in its circle where they find no end. It can be deliberately said that different successive governments are unable to develop a nexus between the conservative and liberal ideology here. 


\section{References}

Al-Quran, 2:229.

Al-Quran, 4:20.

Al-Quran, 4: 32.

Al-Quran, 30:21.

Al-Quran, 65:1-7.

Al-Quran, 96: 1-5.

Baldock, J. Manning, N. Vickerstaff, S. \& Mitton, L.(2012). Social policy.New York: Oxford University Press.

Butt, B. I., \&Asad, A. Z. (2016 a). Social Policy and women status in Pakistan: a situation analysis. Orient Research Journal of Social Sciences, 1(1), 47-62.

Butt, B. I., \& Asad, A. Z. (2016 b).Refutation, relinquishment and inheritance: exploring women's inheritance rights in Pakistan.Pakistan Journal of Social Sciences 36(2), 1001-1009.

Butt, B. I., \&Asad, A. Z. (2017).Factors affecting son preference phenomenon and women familial status in Pakistan. Orient Research Journal of Social Sciences, 2(2), 208-226.

Butt, B. I., Abbas, N. A., \& and Ashiq, U. (2020). Pro-women laws and government masquerading: a description of preindependence and post-independence women legislative framework. Review of Education, Administration and Law, 3 (3), 395-401.

Genasan, P. (2019). Social status of devadasis during the 7th and 8th centuries in Tamilnadu .Journal of East-West Thought, 1, 37-45.

Government of Pakistan, (2021). Economic Survey of Pakistan, 2020-21. Islamabad: Federal Board of Revenue.

. (2020). Political map of Pakistan 2020 5th Edition. http://www.surveyofpakistan.gov.pk/SiteImage/Misc/files/political_map_pak istan.pdf. . (1973). The Constitution of Islamic Republic of Pakistan, 1973.

Khan, A. (2019).The women's movement in Pakistan: activism, Islam and democracy. London: Bloomsbury Academic. 
Kohler, G. (2014). Is There an Asian Welfare State Model«? East and South Asian Trajectories and Approaches to the Welfare State. http://library.fes.de/pdffiles/iez/10619.pdf.

Lee, H, J. (2011). Temple prostitutes: devadasi practice and human trafficking in India, Regent J Int'l , 8:1, 1-18.

Modoodi, S. A. (1996). Tafheem-Ul-Quran, Vol.1. Lahore: AdaraTarjuman-ul-Quran.

Monadal.C. (2017). Temple women: the devadasi tradition of the Chola period. Indian History Congress, 78, 199-206.

Mumtaz, K, \& and Shaheed, K. (1987). Women in Pakistan: one step forward two steps back. Lahore: vanguard Books.

Muzaffar, M. Yaseen, Z. \& Ahmas, A. (2018). Child Marriages in Pakistan: Causes and Consequences, Journal of Indian Studies, Vol 4 Issue 2, 195-207

Qureshi, A. (1997). Her honor: an Islamic critique of the rape laws of Pakistan from a woman-sensitive perspective. Michigan Journal of International Law, 18(2), 287-320.

Shah, D, Haider, G, \& Taj, T. ( 2019). Causes of dropout rate at primary level in Pakistan.International Journal of Curriculum and Instruction, 11(2), 38-74.

Shingal, A. (2015). The devadasi system: temple prostitution in India. UCLA Women's Law Journal, 22(1), 107-123.

Sultana, A. (2012). Patriarchy and women's subordination: a theoretical analysis. The Arts Faculty Journal, July 2010-June 2011,Vol 4 (2010-2011), 1-18.

The Hadith.Sunan Abu-Dawud. 11: 2091.

The Hadith.Tirmidhi.245:3057.

UNDP. (2020). The next frontier: human development and the Anthropocene. http://hdr.undp.org/sites/all/themes/hdr_theme/country-notes/PAK.pdf

Yousaf, M. S. (1417 A.H).Quran Kareem: ma urdutarjuma-o-tafseer.Madina: Shah Fahad Quran Kareem Printing Complex. 